\title{
História e Memória: o caso do Ferrugem
}

\author{
Myrian Sepúlveda dos Santos \\ Departamento de Ciências Sociais/UERJ
}

Resumo

O objetivo deste artigo é analisar o uso da memória pelas Ciências Sociais a partir da investigação de fontes orais e escritas. Ao longo do trabalho, serão consideradas cinco narrativas sobre $o$ assassinato de um lavrador da Ilha Grande por um grupo de presos que havia fugido do Instituto Penal Cândido Mendes (IPCM). Além disso, são objetos de análise a notícia sobre o caso que aparece na imprensa e o relatório oficial sobre a fuga dos presos encaminhado pelo diretor da penitenciária ao diretor-geral do Departamento do Sistema Penitenciário (DESIPE). Em que pese a diferença entre os relatos apresentados, procurar-se-á mostrar que as memórias relacionam-se a perspectivas e códigos existentes entre grupos de pertencimento e que elas podem fornecer dados importantes sobre contextos, processos e conflitos sociais que fazem parte da vida dos diversos narradores do caso em questão.

Palavras-chave: Memória coletiva. Ilha Grande. Presídio. Penitenciária. Violência.

\section{ABSTRACT}

The objective of this paper is to investigate social practices developed by inmates of the Instituto Penal Cândido Mendes (IPCM) as well as by those who lived in Ilha Grande, the island where the prison was settled, through the analysis of different narratives about the escape of a group of convicts. The author also analyzed the escape on the news and on the official reports. The point the author makes is that despite the different reports on the escape it is possible to relate the narrative to collective memories, that is, to common rules and perspectives, which allow us to understand social conflicts, processes and contexts inherent to the lives of the narrators.

Keywords: Collective memory. Ilha Grande. Prison. Penitentiary. Violence. 


\section{INTRODUÇÃO}

"Antecipando-nos ao desfecho da Sindicância instaurada para apurar sobre os fatos relativos à fuga dos internos Pedro Sebastião, RG183.004, Carlos Roberto Matos Martins, RG 2.723.267, Leonel Ferreira Filho, RG 92.281, Edson Silvério dos Santos, RG 160.100 e Pedro Pereira, RG 13.708 - enviamos a Va. S., para um prévio e oficial conhecimento, um relatório informativo, deste constando: termos de declaração dos cidadãos que haviam sido seqüestrados pelos fugitivos e que testemunharam o início da agressão que resultou no assassínio do caseiro de uma fazenda; termos de declarações dos internos Pedro Sebastião e Carlos Roberto Matos Martins, que saíram ilesos dos tiroteios, travado inicialmente contra moradores que rechaçaram os fugitivos em Sítio Forte, e depois contra as forças de recaptura. E para u'a melhor compreensão desse e de outros fatos, enfeixamos tudo com um sucinto e fidedigno resumo sobre certos aspectos que nos parecem de alta relevância, não só em relação a esse episódio isoladamente, como também em relação a tudo o mais que continua afetando os mais comezinhos princípios da boa Administração Penitenciária”. (Relatório 1980:1)

O objetivo deste artigo é levantar algumas questões sobre o uso da memória pelas Ciências Sociais a partir da análise de diferentes versões de um assassinato ocorrido na Ilha Grande. Em 1999, iniciei um trabalho de pesquisa cujo objetivo era, e ainda é, resgatar a história das instituições carcerárias que existiram na Ilha Grande durante praticamente todo o século vinte. Esta história se baseia tanto nas informações retiradas de fontes escritas, quanto nos relatos obtidos junto à população local, antigos presos e funcionários dos presídios que foram lá instalados. Uma das primeiras histórias que me contaram sobre a época do presídio foi o caso do Ferrugem. ${ }^{2}$ Ao longo destes quatro anos de idas e vindas à Ilha Grande, em que são realizadas não só entrevistas formais, mas também observação de campo e participação na vida local, eu obtive diversas outras versões de como teria acontecido o assassinato de Joaquim João Raimundo, um dos moradores da Ilha, em 25 de outubro de 1980, por presos que tinham fugido do presídio.

Ao longo deste trabalho apresentarei algumas destas versões. A primeira é inegavelmente a versão mais popular e difundida, na qual tanto os elementos principais, quanto os detalhes do caso se repetem de forma mais estável. Além dela, escolhi quatro narrativas do caso que me foram relatadas por moradores, nas mais diversas situações. Reproduzo também trechos de uma notícia sobre o caso que foi publicada no Jornal do Brasil, bem como do relatório da fuga dos presos encaminhado pelo diretor do Instituto Penal Cândido 
Mendes (IPCM) ao diretor-geral do Departamento do Sistema Penitenciário (DESIPE).

Ao contrário da maior parte dos depoimentos obtidos, em que aqueles que narravam o caso me asseguravam a veracidade da informação prestada, não tenho a ambição de chegar a contar este caso tal como ele aconteceu. Ainda assim, como veremos, procuro uma verdade nestes depoimentos, verdade esta que não se refere aos diversos elementos presentes no assassinato que aconteceu em 1981, mas aos contextos, processos e conflitos sociais que fazem parte da vida daqueles que narraram as suas versões do passado.

\section{EnTre História E MEMÓRIA}

Lembrar não é a re-excitação de inumeráveis traços fragmentados, fixos e sem vida. É uma reconstrução, ou construção imaginativa, construída a partir de nossa atitude em relação a uma massa ativa de reações ou experiências do passado organizadas, e em relação a pequenos detalhes importantes que comumente aparecem em imagem ou na forma da linguagem. ${ }^{3}$

Nos últimos 30 anos, pesquisadores de diversas vertentes disciplinares passaram a criticar a arbitrariedade pela qual a História ordena e atribui sentido a um conjunto de fatos e eventos que aconteceram no passado. A alternativa encontrada por muitos foi a de procurar compreender o passado através de representações ou memórias coletivas, ou seja, a partir de uma abordagem que procura o sentido atribuído aos fatos passados por aqueles que, de uma forma ou de outra, estavam envolvidos com estes mesmos fatos. ${ }^{4} \mathrm{O}$ passado é recuperado pelo presente através de processos de interação social. A compreensão do passado, neste caso, é composta de uma rede bem mais complexa de significados. São indivíduos em contato com outros indivíduos e em determinados contextos sociais que trazem o passado para o presente. O conceito de memória, portanto, nos permite entrelaçar passado e presente, por um lado, ultrapassar a antinomia teórica clássica entre indivíduo e sociedade, por outro.

Podemos compreender a memória como sendo qualquer forma de pensamento, percepção ou prática que tenha o passado como sua principal referência. A memória de experiências passadas está presente em cada palavra que dizemos, em cada passo que damos ou em cada sonho que construímos. Ela está presente no pensamento, nos sentimentos e percepções, bem como na imaginação. Tudo o que sabemos ou que podemos aprender se deve às me- 
mórias que possuímos ou que iremos adquirir. Mesmo considerando a presença da memória "em nós", precisamos considerar que esse "nós” não é uno e indivisível. Nós não somos capazes de lembrar com todos os detalhes nem mesmo um evento vivenciado algumas horas atrás. Se nos damos conta de que, além de ser seletiva, a memória envolve o esquecimento, podemos compreender melhor ainda a falta de controle que temos sobre ela, pois o que lembramos e esquecemos não é resultado apenas de nossas intenções e desejos declarados. Nós nos lembramos de detalhes aparentemente sem importância e esquecemos de faces, nomes e lugares que seriam fundamentais para nós. $\mathrm{O}$ esquecimento de experiências traumáticas pode acontecer independentemente de nossas vontades.

Podemos dizer ainda que a memória tanto está presente em nós, quanto é, também, exterior a nós. Há objetos que guardam a memória e nos fazem lembrar das mais diversas maneiras. Amarramos um barbante no dedo para não esquecermos uma tarefa importante a fazer e guardamos o souvenir de viagem para guardar a lembrança de momentos felizes. A linguagem é uma forma de memória que nos antecede. Construções coletivas do presente também guardam memórias de experiências passadas. Também nesses casos, a memória que temos do passado não é una e indivisível. A memória se cristaliza fora de nós, em lendas, monumentos e objetos que estão longe de ser reflexos de verdades históricas.

A compreensão de que a memória é resultado de um processo de interação social, e que ela tanto está em nós quanto é exterior a nós, não supera o fato de que a memória como relato do passado é falha e incompleta. Por que esse interesse tão grande pela memória nas Ciências Sociais? Sem dúvida lidamos com a memória porque conhecemos, em parte, suas limitações e acreditamos que podemos fazer dela uma forma de conhecimento. Mas a primeira observação que gostaria de fazer em relação a este debate teórico mais recente é que as fronteiras entre História e memória são intercambiáveis. Embora possa ser útil traçarmos alguns limites entre História e memória, é interessante observarmos que tanto a memória é constituída a partir das narrativas do presente ${ }^{5}$, quanto a História é resultado de experiências que se acumulam ao longo do tempo ${ }^{6}$. Quero dizer com isso, por um lado, que a memória pode ser tão arbitrária quanto a História em relação ao passado e, por outro, que esta última pode ser considerada, da mesma forma que a memória, como sendo o resultado de tradições constituídas. As definições de História e memória, portanto, lidam com fronteiras tênues, e gostaria de defender aqui a visão de que tanto devemos atribuir sentido ao passado, como procurar apreender o sentido atribuído a ele, e que estas duas abordagens devem ser consideradas simultaneamente na nossa tarefa de lidar com o passa- 
do, embora tenhamos claro que História e memória nem sempre sejam complementares. ${ }^{7}$

A segunda observação é que embora a memória seja sempre resultado de um processo interativo, há casos em que a experiência pessoal é fundamental, e outros em que as determinações coletivas precisam ser consideradas. Os pesquisadores que trilham os caminhos da história oral subordinam a memória ao relato dos testemunhos sobre o que aconteceu no passado, inaugurando um novo campo de investigação. ${ }^{8}$ Há historiadores, no entanto, que se voltam para uma etnografia da trama de relações sociais do passado a partir da interpretação de construções simbólicas que não só antecedem, como ultrapassam o conteúdo de relatos obtidos. O estudo sobre a lembrança de velhos que aparece na análise feita por Ecléa Bosi não tem as mesmas características que aquele que se volta para as representações simbólicas analisadas pelos historiadores associados a Pierre Nora na constituição da nação francesa. ${ }^{9}$

Enquanto historiadores procuram, através da memória, pelos diversos componentes que constituíram os contextos culturais do passado, sociólogos e antropólogos elegem a memória coletiva como elemento-chave para a compreensão da constituição de práticas e comunidades imaginárias do presente. Neste caso, não se trata de investigar o passado através da memória, mas de procurar compreender o presente a partir das reconstruções que são feitas do passado. Mas também aqui o conceito de memória pode ser associado tanto a processos interativos quanto a construções simbólicas já constituídas. ${ }^{10}$

Em terceiro lugar, é importante observar que as memórias são resultado de experiências vivenciadas e que estas deixam poucos traços de si em nós. O filósofo Henri Bergson, no seu clássico trabalho sobre a memória, descreveu dois tipos de rememoração, a memória-hábito, que se faz presente em ações e atividades do dia-a-dia, isto é, em hábitos da vida cotidiana, e a memória que recupera imagens à semelhança do passado. O primeiro tipo de memória refere-se à habilidade de reproduzir algo que foi aprendido ao longo da vida. Já o segundo tipo de memória se refere à recordação de um evento do passado, que é colocado no tempo-espaço e não pode se repetir. Bergson atribuiu à memória a capacidade de unir estes dois planos de experiência; creditou à memória a capacidade de nos permitir uma consciência espaço-temporal. ${ }^{11} \mathrm{~A}$ autonomia dada por Bergson às duas formas de memória foi criticada por Benjamin e por outros que o sucederam. ${ }^{12}$

O que é preciso compreender é que indivíduos não armazenam uma totalidade de experiências passadas. Ao lembrar um episódio vivenciado no passado (memória episódica), o indivíduo reconstitui o que aconteceu, primeiro, a partir de uma massa ativa de reações ou experiências do passado organizadas, ou seja, a partir de uma estrutura já existente, como a linguagem, e de uma 
disposição que ele tem para lembrar (que pode ser associada à memória-hábito), e, segundo, a partir dos fragmentos que remanesceram da experiência vivenciada. Podemos dizer, portanto, que estamos sempre reconstituindo o passado a partir do legado que o passado deixou em nós e que o balanço entre as determinações do passado e do presente não é jamais dado a priori. ${ }^{13}$

$\mathrm{Na}$ análise que veremos a seguir sobre as diferentes versões do caso do Ferrugem, farei amplo uso não só dos diferentes elementos que constituem a memória, como de abordagens históricas que nos permitem uma compreensão mais distanciada do período em questão. Na reconstrução do passado, cada relato obtido pode ser associado a um "quadro social" determinado, dependendo da inserção de cada indivíduo em seu grupo. Isto acontece porque indivíduos guardam fragmentos de experiências vivenciadas, e precisam das construções coletivas para que possam correlacionar e dar sentido aos diversos fragmentos que rememoram. Essas construções podem ser pensadas como sendo esquemas inerentes a cada indivíduo ${ }^{14}$, mas também a partir de construções coletivas que os antecedem. ${ }^{15}$

Há especificidades a serem consideradas nas diversas fontes analisadas, pois um relato pessoal, um artigo de jornal e um ofício têm, cada um a seu modo, uma relação própria com o contexto em que se insere. Embora o narrador procure reconstruir o que aconteceu com base em sua própria experiência de vida, ele também tem como referência artigos de jornais e relatos oficiais, em que outros personagens gravaram neles suas próprias versões do acontecido. Veremos, também, que há memórias em que o caráter coletivo é predominante, e memórias cujos componentes pessoais são mais fortes e que este balanço não é determinado pela fonte escolhida. Em um relatório oficial encontramos uma construção coletiva consolidada, ao mesmo tempo em que referências à memória pessoal daqueles que se encontravam reunidos quando souberam da fuga ou ao depoimento de testemunhos, que rompem com a lógica do narrador principal. Na posição inversa, gravamos relatos pessoais que reproduzem com variações mínimas uma narrativa consolidada oficialmente.

Por último, gostaria de chamar a atenção para o fato de que a memória também traz com ela indicações sobre as rupturas no diálogo entre passado e presente. $\mathrm{O}$ caso Ferrugem certamente envolve situações traumáticas não só para os que participaram mais de perto do acontecido, mas para todos os moradores da Ilha, pois estavam todos eles sob pressão diante da possibilidade da violência e morte nos seus quintais. As diversas formas de registro do passado certamente trazem aspectos que fogem ao controle dos que registraram o acontecido. Ao longo deste artigo, portanto, será mostrado que nós não temos apenas um tipo de memória, uma única forma de nos lembrarmos do passado, e que passado e presente se entrelaçam de acordo com múltiplos fatores. 


\section{Memória Coletiva e Memória INDIVIDUAL}

Havia um homem muito grande, de quase dois metros de altura, que batia com a cabeça no teto da porta. Ele era claro e tinha o rosto todo enferrujado, com muitas sardas, daí o nome Ferrugem. Morava no Sítio Forte. Ele sempre prendia os presos que passavam por lá fugidos e batia neles. Ele tinha cinco filhas, elas tinham o cabelo bem pretinho. A mulher era meio índia. Ele morava numa casa branca, com varanda, e nos fundos tinha um quarto pequeno, 4 por 4, com barras de ferro. Ali ele prendia os que fugiam do presídio e tinham o azar de esbarrar com ele. Surrava os presos com camarão (um tipo de cipó). Os presos iam riscando traços nas paredes do quartinho para marcar o número de dias que ficavam presos lá. Um dia, ele prendeu um escuro forte que havia fugido e bateu muito nele. O escuro escreveu nas paredes do quartinho: "Pode passar o tempo que passar, eu vou voltar e me vingar. Só eu sei o preço da minha liberdade." O Ferrugem não tinha medo, arrastou ele do Sítio Forte até Dois Rios. Em cada ponto que eles paravam e que o preso era surrado, ele jurava voltar e se vingar. Dito e feito. Um dia esse preso fugiu do presídio, se juntou com outros presos que também estavam fugindo, e foi atrás do Ferrugem. Voltou, disputou com o Ferrugem na briga e na faca. Ganhou a briga. Matou e esquartejou o Ferrugem, e deixou os pedaços dele em cada um daqueles pontos em que ele tinha sido surrado. Quem, depois, foi achar os pedaços do corpo foi a cachorrinha do Ferrugem (moradora de Angra)

Todo mundo tinha arma aqui, às vezes o chumbo saía, mas não se sabe de onde. Tempo difícil, ninguém gostava. Houve um caso, onde o Ferrugem e mais alguém surraram e torturaram um preso a ponto de arrancar a orelha do preso. Um dia, os presos voltaram e vararam ele de bala. Era muita bala. A mulher fugiu (morador do Aventureiro).

Quando o Ferrugem morreu, eu estava vindo de Angra e soube do que aconteceu. Posso contar o que aconteceu de verdade. Três presos fugiram de Dois Rios, um tinha vindo de fora. Eles renderam o Manoel, aquele pescador que está passando ali, de refém, e fizeram com que ele os levasse até a casa do Ferrugem. Manoel foi pego no caminho de Dois Rios para a Parnaioca. O Ferrugem morava na Praia do Leste, perto da saída da trilha, numa casa grande, com a mulher e os filhos. Fizeram com que o Manoel os levasse até a casa do Ferrugem, mas não encontraram ele lá. Um dos presos ainda quis estuprar a filha dele, mas o outro não deixou. Acabaram encontrando o Ferrugem e a mulher perto do Sítio Forte. Mandaram o refém embora, e a mulher, que também seria assassinada, con- 
seguiu fugir. Mas eles pegaram o Ferrugem e o mataram com facadas. Cortaram as partes dele e deixaram por aí. Como ele sempre usava camisas de mangas compridas, os presos colocaram pedaços de pano dentro dos ferimentos. Os três presos apareceram depois mortos no Abraão. O Ferrugem além de fazer o trabalho da polícia, que é prender os presos fugidos, torturava e surrava os presos. Uma vez eu e minha cunhada vimos ele passar aqui na Parnaioca com um preso, que já tinha sido surrado e estava sendo arrastado pela praia desde o Aventureiro. Meu marido trabalhou em Dois Rios, mas os presos nunca tiveram nada contra ele. Eles fugiam, passavam por aqui e não faziam nada. Às vezes roubavam uma coisa ou outra, mas era só. Eu às vezes dava alimento para eles, fazia café, para dar tempo dos policiais chegarem" (moradora da Parnaioca, mulher de um guarda do IPCM).

A primeira versão que obtive do caso Ferrugem foi de uma moradora de Angra. Ao saber que minha pesquisa relacionava-se ao presídio, ela me contou a história tal como está descrita acima. De alguma forma, o assassinato do lavrador Joaquim João Raimundo tornou-se uma lenda, que não pertence mais aos seus parentes e amigos mais próximos, nem mesmo aos moradores da Ilha. Alguns meses mais tarde encontrei a mesma pessoa e comentei, então, que ouvira uma outra versão da história que me fora contada por ela. Percebi que tinha sido indelicada, como se estivesse duvidando da honestidade do informante. A história, então, foi recontada. O que pude observar é que a história se repetia com uma enorme precisão. Os mesmos elementos e detalhes da história anteriormente contados foram reiterados. Essa primeira versão, bastante consolidada e que é contada com variantes muito pequenas, traz de forma muito explícita a condenação moral de Ferrugem, o morador que torturava os presos e que foi vingado de morte. Ouvi, mais tarde, de outros moradores, donos de pousada, contadores das histórias da Ilha, praticamente a mesma versão. Eu diria mesmo que esta é a versão que está na memória da maior parte das pessoas que conta a história, é a versão que preserva o arcabouço central dos eventos. O caso adquire uma conotação de justiça, uma vez que se trata da luta do torturado contra o torturador, do negro contra o branco, que responde à agressão sofrida com o mesmo tipo de agressão. Trata-se da justiça popular, aquela do "olho-por-olho, dente-por-dente".

O relato do caso por dois moradores de locais próximos onde aconteceu o assassinato do lavrador se aproxima bastante do relato que me foi contado inicialmente pela moradora de Angra. Esses dois moradores, entretanto, estiveram muito próximos do evento e suas memórias trazem à tona outros elementos, além daqueles que estão presentes na versão popularizada. Os dois relatos também podem ser resumidos como sendo a história de um homem 
que torturava os presos que fugiam do presídio e que foi justiçado por eles. A descrição da violência sofrida por ambas as partes aparece nos relatos: "arrancaram a orelha do preso", "cortaram as partes dele e espalharam por aî", "colocaram pedaços de pano dentro dos ferimentos".

Segundo o morador do Aventureiro, a presença do presídio na Ilha trazia insegurança para os pescadores e lavradores que lá viviam. Embora nunca tivesse havido estupro no vilarejo, esse era o medo das mulheres. Quando um "vagabundo" era visto nas praias vizinhas, as mulheres trancavam as casas e corriam com as crianças para uma das casas onde se sentiam em maior segurança. Às vezes, quando os pescadores saím para a pesca, só as mulheres ficavam na vila. No Aventureiro, houve diversos casos de conflito entre pescadores e "vagabundos". Para eles, havia alguns bons policiais que pegavam os presos, mas tinha guarda "que não queria ir atrás". Os moradores apontavam a direção para onde os presos tinham ido, mas, segundo eles, os guardas davam a volta e iam embora. Eles andavam armados e algumas vezes usavam as armas para se defenderem. Apesar de se encontrarem, portanto, em situação semelhante à do Ferrugem, os moradores recriminavam os policiais por não manterem a região em segurança e, em seus depoimentos, mostravam a desaprovação às torturas e o compromisso com policiais mantido por ele.

A memória que se populariza ganha certa autonomia em relação aos membros de um grupo social e distancia-se da memória que guarda cada indivíduo sobre aquele acontecimento. Alguns elementos centrais, no entanto, costumam permanecer. No caso do Ferrugem, aqueles que estavam relacionados de forma muito próxima ao que acontecera guardam lembranças que não são exatamente a mesma, cada um deles tem um detalhe a contar que não aparece na lembrança dos outros, e que, às vezes, é até mesmo contraditório com o relato seguinte, mas em que pesem as diferenças, encontramos tanto nos relatos individuais quanto na história que já assumiu um formato mais consolidado o mesmo elemento central: o acerto de contas entre o torturado e seu algoz.

Memória Coletiva e Memória Oficial

Às 15:10 horas, como dizíamos, recebemos a notícia de que 4 internos (3 em visitação e 1 colono livre) não responderam ao confere, e que tudo indicava que se tivessem juntado a um outro (cuja saída fora autorizada por papeleta), e que os cinco haviam empreendido fuga, procurando para isso a rota do Sítio Forte. Ao começarmos os planos para evitar o sucesso da fuga, chegaram-nos informes de 
que de nada adiantaria tentar a recaptura, pois a fuga era certa, uma vez que os 5 internos portavam armas de fogo (esse informe foi trazido por internos). (...) Pouco antes das 19:30 horas foi-nos informado, pelo Destacamento de Policiamento Ostensivo, que um morador do Sítio Forte viera de barco até Vila do Abraão, e deu a notícia de que 5 presos foragidos haviam atacado um casal de colonos (lavradores, caseiros), preocupando-se com o homem, em quem desfecharam vários tiros, e não conseguindo evitar que a mulher escapasse, apesar de a terem perseguido, depois, a boa distância; e que esta chegando ao local exato de Sítio Forte, comunicou aos demais moradores que alguns presos haviam atirado em seu marido e que deveriam estar vindo para Sítio Forte; o que de fato ocorrera, tendo sido os fugitivos rechaçados a tiros, em resposta aos disparos de arma-de-fogo efetuados pelos ditos fugitivos. (...)

Cerca das 9:30 horas, já no domingo, dia 26, chegaram à presença do chefe de segurança, que os conduziu à residência do diretor, os 3 cidadãos que haviam sido seqüestrados (...). Quando chegaram próximo a uma curva da trilha, em pequeno aclive - portanto, com muito reduzida visão do que estava pela frente -, ouviram sinais de que vinha alguém em sentido contrário. O preso da frente (mais tarde soubemos que era o vulgo "Carequinha", que, em fuga anterior, já houvera sido recapturado naquelas adjacências pelo lavrador), decerto lembrando-se do passado, inferiu que fosse o caseiro que se aproximasse e correu velozmente, deparando-se com esse colono, Sr. Joaquim João Raimundo, conhecido por Ferrugem. Este, admitindo poder enfrentar a situação, sacou da faca; o preso atirou várias vezes; os gritos foram ouvidos; o grupo acercou-se mais; o quadro visto por todos. Ao mesmo tempo, o preso que cerrava o grupo veio de trás em velocíssima carreira, passando à frente das seis pessoas que o separavam do primeiro, juntou-se a este e continuou a agressão, agora com arma de grosso calibre, já com a vítima caída, a mulher correndo para a direção de onde estava vindo, e os reféns aproveitando-se do momento para também fugirem, em desabalada carreira, no caminho de retorno para a Fazenda do Leste (Relatório 1980:1-4).

Mas se a memória coletiva não se confunde com as memórias individuais, talvez ela se confunda com a memória oficial, isto é, a memória que está presente nos documentos oficiais, deixados por instituições públicas que detêm legitimidade e autoridade junto à população. A instalação das instituições carcerárias na Ilha Grande sem dúvida transformou completamente os moradores da Ilha, pescadores e lavradores pobres, que aos poucos foram sendo totalmente absorvidos pela dinâmica imposta por elas. Até hoje é comum percebermos um sentimento nostálgico em relação aos tempos do presídio, 
em que a população tinha maior proteção institucional. O IPCM, portanto, foi uma instituição de prestígio no local.

O relatório do caso feito pelo diretor do IPCM me foi entregue por um dos policiais que participaram da equipe de vigilantes e que foram atrás dos fugitivos. Este policial está hoje aposentado e guarda até hoje uma série de documentos relativos ao IPCM. Através de entrevistas realizadas com antigos moradores da Vila Dois Rios, conseguimos descobrir não só alguns documentos que estavam se deteriorando nas ruínas do presídio, como o fato de que diversos documentos tinham sido transferidos para a Penitenciária Vicente Piragibe, no complexo de Bangu. Hoje estes documentos encontram-se no Arquivo do Estado, ainda em estado precário de conservação e consulta. No entanto, fotos, filmes, cartas e documentos importantes, relativos a fugas, inquéritos e processos encontram-se ainda hoje nas mãos de alguns dos guardas que trabalharam no presídio.

A desativação do presídio é condenada por todos aqueles que lá trabalhavam ou tinham parentes, ou mesmo atividades econômicas ligadas à vida da prisão, ou seja, por um número muito grande de moradores. Guardas e PMs eram recrutados entre moradores e há ainda hoje na Ilha o que podemos chamar de cultura do presídio, formada por diversas gerações de moradores. Para os antigos funcionários do IPCM, guardar a memória do presídio é guardar a memória de um passado de que eles se orgulham de ter participado. Durante a época do presídio, os moradores tinham uma instituição do governo a lhes dar emprego, bons salários, dignidade e respeito. Eles viram que foram deixados no interior do presídio na época da implosão vários documentos, móveis, objetos.

Sobre o relatório, um documento oficial, é interessante observar seus vínculos com a memória. Ele é feito a partir de diversos relatos e depoimentos pessoais. A primeira descrição da agressão sofrida por Ferrugem aparece como sendo resultado do depoimento de um "morador do Sítio Forte (que) viera de barco até Vila do Abraão". Em outra passagem lemos que "sem que saibamos precisar a fonte, chegaram notícias...". São citados também os relatos dos reféns e de outras pessoas envolvidas. Além disso, a guarda desses documentos por antigos funcionários faz parte da luta da memória contra o esquecimento. A memória é um caminho para que o homem consiga se inserir com dignidade no mundo em que vive, e os moradores preocupam-se com a memória das antigas instituições carcerárias.

Apesar de eu estar presente na Ilha nos últimos quatro anos e ser identificada com o projeto de construção de um museu que procura integrar os moradores na formulação de seus objetivos principais, só em alguns casos tive acesso aos documentos que são guardados. Quando os documentos me são 
entregues, há sempre o pedido de que eles sejam preservados em lugar seguro. A UERJ e outras instituições governamentais que hoje estão presentes na Ilha não adquiriram ainda a legitimidade do "antigo presídio", nome por que é chamado o Instituto Penal Cândido Mendes.

A versão que encontramos no relatório oficial é a que mais difere daquela inicialmente apresentada. Enquanto nesta última o preso que é torturado volta para se vingar de humilhações e torturas previamente sofridas, na versão oficial o encontro entre os fugitivos e o Ferrugem se dá ao acaso. Os presos se defrontam com o Ferrugem e a mulher no seu trajeto de fuga e, como este está armado de facão e os ataca, eles o matam. Apesar de o relatório oficial apoiar-se no depoimento de três reféns que foram feitos pelos presos, não há menção de que eles tenham ido inicialmente ao sítio onde moravam Ferrugem e sua família, como relatado pela moradora da Parnaioca. Outra diferença importante é que enquanto na versão coletiva não há nenhuma menção sobre o que acontece com os assassinos e a história acaba com a morte do colono, fechando o ciclo da violência, na versão oficial vários detalhes são descritos em relação ao que acontece após o assassinato. Na perspectiva dos guardas e PMs, o caso se tratava de mais uma fuga coletiva, cuja captura dos fugitivos era sua tarefa principal.

Se o encontro entre o Ferrugem foi obra do acaso ou resultado da intenção dos presos não está claro. Mas o que é evidente é que enquanto nas versões anteriores há a condenação moral do lavrador e a história se passa como se fosse um ajuste de contas entre ele e o preso que fora torturado, na versão oficial a história que é descrita é a de um grupo de presos que fogem, assassinam um homem bravo e corajoso e são recapturados pelos policiais. Apesar de grande número de moradores ser também funcionário ou parente de funcionários do presídio, a versão oficial não é aquela que aparece na maior parte dos relatos.

\section{MEMÓRIA do Opressor E MEMÓRIA DO OPRIMIDO}

O Ferrugem morava no Sítio Forte. Eu sempre ia lá. Aqui tinha umas éguas, mas não tinha cavalo. Quer dizer que tinha que levar a égua para cruzar lá. De maneira que eu sempre ia lá com seu Jairo, dono de uma fazendinha que tinha lá. De maneira que o Ferrugem morava lá. Ele sempre ficava atento ao pessoal que fugia daqui pra lá e passando por lá, ele às vezes prendia com uma equipe e retornava aqui, de acordo com o vagabundo. Não eram todos. E quando ele não podia impedir, ele vinha aqui e cagüetava na administração. Os internos saben- 
do disso aí passaram a não gostar dele. Até que um dia fugiu uma equipe de três, eles foram lá, encontraram ele e mataram ele. Então eu conheci ele e a família dele que mora em Angra dos Reis. Ele prendia, amarrava, entregava na administração. A administração corrupta. Eu não me recordo como foi a morte dele. Não sei o que aconteceu com ele. O pessoal que conta a história quer bravura. Negativo. E aí o que aconteceu com os presos que mataram ele? Só falam que mataram ele, mas que mataram os presos aqui no Abraão... Prenderam eles na fuga, prenderam e mataram os três. Esqueci o nome deles. Mas tem pessoas no Abraão que estão envolvidas nesses crimes. Funcionários. Essa parte... não tocam no assunto (preso do IPCM).

Eu posso contar a história do Ferrugem. Fiz parte do grupo que fez a diligência para pegar os presos que haviam fugido. Cinco presos haviam fugido do presídio. Pedro Sebastião, Pedro Maneco, Leonel Ferreira, Pleibolo e um tal de Carequinha. O Pleibolo, mais tarde, foi esfaqueado na Ilha Grande. Pedro Sebastião levou um tiro na barriga e morreu. O Pedro Maneco morreu logo depois, fugiu daqui, era chefe do Borel e acabou morrendo por lá. Eles fugiram do presídio e no caminho para a Parnaioca seqüestraram o Manoel. Depois, quando estavam perto do Sítio Forte se depararam com o Ferrugem. Os presos não gostavam do Ferrugem e conheciam sua fama. Quando encontraram o Ferrugem, viram que ele tinha só uma faca. Os presos estavam armados. Fuzilaram o Ferrugem. Não havia a intenção deliberada de matar o Ferrugem, mas os presos não gostavam dele. Sabiam que ele trocava presos por "furniço".16 Quando encontraram o Ferrugem, ele carregava cachaça, mantimentos, balas e doces. Os presos beberam, comeram e foram parar no Sítio Forte. Foram logo pegos. Estavam bêbados. Eu estava no grupo de policiais que capturou os presos. O corpo do Ferrugem foi levado pelos policiais para o Abraão. Eles rasgaram a camisa do Ferrugem para estancar o sangue que corria dos ferimentos, pois o corpo estava varado de balas. Se não fizessem isso, o corpo não chegava no Abraão. Amarraram os pés e as mãos dele em um pedaço de pau e o carregaram para lá (guarda do IPCM).

Guardas e presos partilhavam códigos comuns, e conviviam cotidianamente na Vila Dois Rios. Dos cinco presos que fugiram, quatro deles estavam vivendo fora dos muros do presídio, três porque estavam recebendo suas visitas, e um porque pertencia ao grupo denominado "colono livre". Havia um bom número de presos que, por bom comportamento, era deixado em liberdade parcial, fora dos muros do presídio, muitas vezes acompanhados de familiares. Algumas ofensas feitas pelos presos não eram aceitas pelos guardas e policiais, que se sentiam desrespeitados. Aceitava-se, no entanto, como se fosse da natureza do preso a tentativa de fuga. Cabia ao preso tentar fugir e ca- 
bia aos guardas recapturá-los e castigá-los para desestimular o desejo de fuga. $\mathrm{O}$ jogo de violência estava contido nesta malha. Não interessava aos presos que fugiam nem reagir aos "cachorrinhos do mato" - nome que era dado aos guardas e policiais que saíam para recapturá-los, pois a reação dos guardas poderia ser muito violenta contra eles e contra os que ficavam nem aos moradores locais, pois os novos fugitivos sempre precisariam do apoio deles. Evidentemente que as normas têm exceções e a população local preocupava-se com elas. Além disso, os moradores não gostavam de serem feitos reféns, perderem seus barcos e serem roubados. A percepção das fugas era uma para pescadores, outra para os guardas, e ainda outra para os que fugiam.

Uma das versões do caso Ferrugem me foi dada por um cidadão que esteve preso muitos anos no IPCM e que lá se encontrava em 1980 como colono livre. Ele parecia conhecer a história que se contava, mas, ironizando a versão popular por seu anseio por "bravura", me convidou a investigar o que teria acontecido com aqueles que fugiram e assassinaram o colono. A memória individual neste caso reconhece a memória coletiva, mas dela se distancia. $\mathrm{Na}$ memória do ex-preso ficou preservada a violência que ocorrera contra aqueles com quem se identificava, os presos fugitivos, muito embora não se lembrasse de seus nomes ou mesmo quem eram e quantos eram ao certo. Bem presente também nesta narrativa está o Ferrugem como sendo alguém que prendia e entregava os presos aos policiais. Nenhuma lembrança havia de como os fugitivos o tinham assassinado. Além disso, a narrativa dilui o conflito entre o colono e o preso, ao chamar a atenção para a violência e impunidade de guardas penitenciários e PMs. A história, portanto, tem uma moral em aberto, pois o Ferrugem é assassinado por presos, que são assassinados por guardas, que são corruptos e continuam impunes.

A narrativa que representa a face oposta da que apresentamos acima é, sem dúvida, aquela de um dos guardas que participaram da equipe que foi recapturar os fugitivos. Há praticamente um diálogo entre elas. Em primeiro lugar, em contraposição à versão popularizada do caso, o guarda também mostrava certa ironia em relação à vontade do povo em "aumentar" as histórias. Em segundo lugar, os fatos lembrados relacionam-se basicamente aos presos que fugiram e assassinaram o colono. Na narrativa do guarda, o assassinato surge como um acidente, em que ambas as partes perdem, o colono que é assassinado, e os presos que são pegos e punidos. O caso Ferrugem era mais um caso de fuga de presos, em que estes no seu trajeto assassinaram um morador, mas foram pegos logo em seguida. $O$ fato de que guardas e policiais, por um lado, e presos ou apenados, por outro, compartilhem uma série de códigos comuns não implica de forma alguma o apaziguamento do conflito 
entre eles. A diferença entre eles pode ser percebida nas diferentes conotações que são dadas aos protagonistas da história relembrada. Na memória do preso, Ferrugem é lembrado como um alcagüete, na do outro, um morador corajoso que prestava serviço ao presídio.

Em relação aos processos de lembrança e esquecimento, é interessante observar que a versão do guarda é bem próxima daquela encontrada no relatório oficial. Embora os detalhes possam diferir, nos dois casos fica aparente que o núcleo do caso rememorado é o de que os "vagabundos mataram um cidadão e foram punidos". Ainda que o guarda relate alguns fatos de forma diferente daquela que encontramos no relatório (número de reféns, nomes, etc.), o conteúdo principal do seu depoimento pode ser reconhecido no relatório oficial.

Há na narrativa do guarda uma descrição positiva do lavrador, que mantinha vínculos com os responsáveis por manter a ordem, e negativa dos fugitivos, que o assassinaram e logo se embriagaram. Na versão oficial, Ferrugem é descrito basicamente como sendo um homem corajoso:

Viríamos a saber pouco depois, pelos cidadãos seqüestrados, que o lavrador homem bravo, destemido, já acostumado a enfrentar e capturar presos evadidos - reagiu ao ataque do primeiro que o agrediu, puxando uma faca que portava, mas recebendo o primeiro tiro, quase à queima-roupa, e cambaleando logo (Relatório 1980:4).

Os atos de barbárie cometidos pelos fugitivos são ressaltados no relatório oficial:

Dia seguinte, pela manhã, tivemos a confirmação de que o lavrador havia sido realmente assassinado, e com requintes de perversidade, de ódio; mais de 20 tiros e muitas facadas, que lhes desfiguraram o rosto e dilaceraram a região do tórax, com ferimentos profundos e largos, tendo ficado uma das facas cravada nas costas (Relatório 1980:4).

É necessário, ainda, dizer que quando apontamos aqui alguma especificidade em relação à memória do guarda, estamos nos referindo também a uma memória local. A moradora da Parnaioca é a mulher de um guarda que hoje está aposentado. Muitos dos guardas e policiais do presídio eram nativos da região. Este mesmo relatório sobre as fugas do dia 25 de outubro, termina solicitando a contratação de guardas entre os moradores da Ilha, uma vez

(...) que encontramos mais de 40 jovens com idade entre 20 e 25 anos que alme- 
jam avidamente por isso (é excusado dizer que estes são filhos ou parentes daqueles o que, de certa forma, parece garantir, à primeira vista, a boa qualidade da mão-de-obra e outras vantagens mais)" (Relatório 1980:13-14).

Em suma, enquanto o preso se recorda de medidas de violência e impunidade realizadas pelos guardas e pelo sistema, pela "administração", o guarda se recorda do oposto, da intervenção de guardas e do sistema para acabaram com a impunidade. A violência que é lembrada por um é a dos policiais contra os presos, a violência lembrada pelo outro a do preso contra o morador. A lembrança do guarda que nos foi transmitida tem diversos elementos comuns com a lembrança da maioria dos guardas e policiais que estiveram envolvidos no caso. Os guardas e policiais compartilham valores e perspectivas que os fazem olhar para um fato de uma maneira própria; ao contarem e recontarem um determinado acontecimento, eles constroem uma determinada versão coletiva do que aconteceu no passado. O processo de rememorar é um ajuste de contas contínuo com o passado; nele há tentativa intermitente de compor as peças de um quebra-cabeça da melhor forma possível, daquela que é mais racional para aquele que narra o evento passado. Quando passamos a analisar a memória do guarda tendo como base as notícias sobre a Ilha Grande, que a partir de 1980 passam a encher as páginas de jornais, vemos que de opressora, a memória do guarda se torna a do oprimido.

\section{Memória Coletiva, Memória Oficial e Meios de ComunicaÇão de Massa}

Inquérito parou há quatro meses

Dona Teresa Joaquina de Almeida, 33 anos, oito filhos, cujo marido foi morto por cinco detentos na Fazenda do Leste - um lugarejo a três horas de traineira do presídio - afirmou que não voltará a depor hoje num inquérito que se arrasta há quatro meses. Ela conseguiu emprego numa fábrica de sardinhas e considera tudo inútil:

"Além da perda de tempo, nunca me puseram diante dos assassinos. Sei que cortaram os cabelos e arrancaram a barba. Mas posso identificá-los — o pescoço deles continua no mesmo lugar."

O marido, João Raimundo, um lavrador que enfrentava e prendia os presidiários que atravessavam as terras da Praia do Leste, estava jurado de morte há muito tempo. Quando o mataram, gritaram para a mulher: "Teresa, agora se cuide que da próxima vez será você.” A mulher correu gritando: “Me ajude, meu Deus, 
me dá forças para acabar de criar as crianças." Os parentes vieram socorrê-la e travou-se um tiroteio. O corpo de João Raimundo, o Ferrugem, foi resgatado e tinha nove tiros nas costas.

Teresa ficou com tanto medo que não voltou mais ao lugar para recolher três sacas de feijão e oito de milho. Os presos mandaram também um recado por ela para a comadre Leda, que mora no Sítio Forte: “Os parentes podem começar a rezar para aprender a não dar com a língua nos dentes."

Outros moradores da Praia do Aventureiro também foram jurados de morte pelos presidiários que atacaram $\mathrm{D}$. Teresa e assassinaram seu marido. Antonio Osório, Clementino Silva e o compadre, Rosendo. Na Ilha Grande, habitada por quase oito mil pessoas, quase todos se conhecem e se comunicam através dos pescadores que vivem apavorados com os últimos ataques desde a morte de Ferrugem (Jornal do Brasil — 21 de abril de 1981).

À hora em que chegamos ao Abraão, constatamos um enorme aglomerado de moradores em torno do DPO, onde se encontravam os ex-fugitivos; a tensão emocional da população estava no auge. As mulheres de dois dos presos - segundo informes eram as mesmas que pouco antes bebiam comemorando a fuga que supunham certa - choravam, berravam, gritavam desesperadamente, supondo que os respectivos companheiros estivessem mortos, pois chegaram a ver o momento em que a Força de recaptura e os presos desembarcaram da lancha, sendo alguns destes carregados por funcionários para o prédio do DPO, enquanto os ilesos seguiam algemados. (...) Mais tarde, já às 01:30 horas do dia 27, soubemos que não houve autuação, tendo-se processado somente o registro de ocorrência" (Relatório 1980, pp. 6-7).

Vimos anteriormente que o guarda se recordava muito bem dos fugitivos, mostrando memória acurada em relação aos nomes e posterior destino dos presos que haviam fugido. Sua lembrança tão detalhada do destino dos presos talvez se deva à pressão a que começavam a ser submetidos os guardas para que os presos recebessem tratamentos menos violentos.

A narrativa do guarda dá a compreender que um dos fugitivos tinha morrido no conflito, sendo que este fato é complementado com o relato da morte posterior dos outros membros do grupo por razões outras e em circunstâncias diversas. Como vimos, a memória do guarda traz diversos elementos que estão presentes no relatório oficial. Neste sobram os detalhes sobre o estado de alcoolismo dos presos e de suas mulheres. Quanto ao tratamento dispensado aos presos, o relatório também não é muito preciso:

Fomos para Vila Abraão, tendo constatado que dois dos recapturados estavam ile- 
sos, mas que os outros três tinham sido feridos durante o tiroteio. (...) Não foi infligido, em momento algum, qualquer tipo de maltrato aos internos após recaptura, exceto, evidentemente, aquilo que se passou no entrechoque, e que encontra amparo, pelo menos à primeira vista, no estrito cumprimento do dever legal ou mesmo na legítima defesa, ainda que putativa, pois os embates ocorreram no mato, sem visão plena para os agentes das forças legais (Relatório 1980, pp. 6-7).

Poderíamos dizer que em todas as narrativas do caso Ferrugem que foram transcritas até agora está presente um conflito de maiores proporções que ocorre na sociedade. Se prestarmos atenção às primeiras linhas do relatório, que são reproduzidas no início deste artigo, nos damos conta de que ele é escrito com o intuito de se antecipar à sindicância instaurada para averiguar os fatos relativos àquela fuga. Além disso, lemos, no parágrafo seguinte, que os guardas souberam da fuga quando:

Às 15:10 horas do sábado, dia 25-1-80, desenvolvia-se, na residência do Diretor, uma reunião com a finalidade de proceder a um estudo sobre noticiário difundido pelos costumeiros meios de comunicação (jornais, rádios, televisão e revistas) no decurso daquela semana - noticiário este, cujas negativas conseqüências fizeram-se sentir de imediato no meio da coletividade carcerária; e buscava-se, também, o encontro de solução para os problemas já àquela altura emergentes e para os que, fatalmente, acabariam por ocorrer em turbilhão, como de fato vem acontecendo; o que não é de espantar e é uma confirmação da retrospectiva histórica do ano de 1978, quando se falou e começou-se a executar a desativação (Relatório 1980, p. 1).

Os funcionários do presídio se reuniam para avaliar as notícias sobre a desativação do presídio que saíam na imprensa e o relatório é composto por 15 laudas, das quais 9 delas são destinadas à descrição das dificuldades que tinham os funcionários do presídio para manter a ordem e segurança. O caso Ferrugem pode também ser compreendido como um caso exemplar na substituição de políticas de controle pela truculência por políticas que têm como base a garantia dos direitos humanos. Ele é vítima da mudança de regras que desregula o sistema prisional estabelecido, sem que, no entanto, seja capaz de implementar um novo sistema livre de corrupção, violência e demagogia. No entanto, as dimensões mais gerais deste caso não são percebidas a partir dos relatos obtidos. Aqui estão as fronteiras entre memória e história. Embora o caso Ferrugem expresse uma condição mais geral em que se inseriam todos os moradores da Ilha Grande, há um limite na construção da rede de significados do que lá aconteceu. È por isso, que, algumas vezes, precisamos tam- 
bém utilizar alguma arbitrariedade e afastamento para compreender elos que não são imediatamente oferecidos a nós, pesquisadores.

Gostaria, portanto, de dar como início da história do assassinato do Ferrugem o ano de 1978. A partir deste ano, as críticas ao isolamento e maus tratos sofridos pelos presos chegavam à imprensa. Diversas vozes da sociedade civil começavam a aparecer publicamente para denunciar o sistema penitenciário por não ser capaz de reintegrar os apenados à sociedade. A partir da leitura de um outro relatório, este escrito em setembro de 1979 pelo então diretor do IPCM, capitão Nélson Bastos Salmon, para o DESIPE, ficamos sabendo que após os assassinatos de setembro daquele mesmo ano, a "Falange da Lei de Segurança Nacional", ou "Comando Vermelho", teria exterminado a Falange do Jacaré e passado a imperar no presídio da Ilha Grande, comandando o crime organizado em todo o sistema penitenciário do Rio.

Embora não seja o objetivo aqui analisar o crime organizado, é interessante observar que ele assume de forma extremamente eficiente o controle dos presos, gerenciando comportamentos, direcionando ações e possibilitando fugas. O enfraquecimento do poder de guardas e policiais de controle do que acontece no interior do presídio é notório. As notícias sobre a desativação da Ilha Grande ocasionavam rebeliões organizadas dentro do presídio, uma vez que as lideranças criminosas não tinham interesse em sair do presídio da Ilha Grande, já que tinham acabado de obter imenso controle sobre os demais presos. Os guardas atribuem até hoje à imprensa responsabilidade pela deterioração de sua autoridade.

No entanto, desde 1971, a imprensa divulgava que havia intenção do governo do Estado de desativar o presídio e transformar toda a área ocupada por ele em um complexo turístico. Já nessa época denunciava-se o alto custo operacional do presídio. Na década de 70, entretanto, um presídio de segurança máxima era necessário, pois para lá eram enviados diversos opositores do regime militar. As notícias não eram capazes de desestabilizar o sistema de segurança. Mas a partir de 1978, ainda no governo de Faria Lima, intensificaram-se as declarações de lideranças do governo do Estado sobre a necessidade de desativação do Conjunto Penal Cândido Mendes, na Ilha Grande. Entre os motivos havia não só o alto custo de manutenção do presídio, mas também a ineficiência de um sistema que isolava os apenados de laços familiares e da vida social.

A memória do guarda que reproduzimos aqui é, portanto, a memória daquele funcionário que está colocado entre dois mundos, o do controle tradicional dos presos através da tortura, que era internalizada e naturalizada como forma disciplinar mantenedora da ordem, e o de uma nova situação constituída, por um lado, pela organização interna e aumento do poder de 
rebelião dos presos e, por outro, por um momento de abertura democrática em que os sistemas de controle baseados na violência física são denunciados. Para os antigos guardas, a tortura, espancamento e morte eram resultado do estrito cumprimento do dever legal. Para isso eram treinados e condecorados. As ameaças de sindicância e prisão para os guardas e policiais que desrespeitavam os direitos humanos começaram a surgir em 1978, muito embora medidas disciplinares só tenham sido efetivamente implementadas a partir de 1983, quando o governador Leonel Brizola e seu secretário de Segurança, Vivaldo Barbosa, elegeram o aperfeiçoamento do sistema carcerário do Estado como um dos objetivos principais do governo. Mas, em 1980, ano em que o Ferrugem foi assassinado, é a imprensa que aparece para os policiais como sendo a principal responsável por perturbar a ordem do presídio.

Na notícia publicada no Jornal do Brasil, observamos que, longe da construção que fizeram os moradores da Ilha, Ferrugem é identificado aos demais pescadores no conflito. Além disso, há uma cobrança de responsabilidade ao poder público pela não-resolução do inquérito que é instaurado para apurar o acontecido. Pela forma que a matéria é construída compreendemos que os assassinos não foram punidos por este crime. Parece mesmo que há dificuldade na identificação dos presos, quando pelo relatório citado vemos que o nome dos presos foi imediatamente repassado ao DESIPE. O silêncio em relação aos policiais envolvidos no caso é evidentemente acusatório, pois eles eram os responsáveis pela prisão do(s) assassino(s). Novas contradições que nos levam apenas à constatação de que nem todos os dados que envolveram o evento estão apresentados nesta exposição.

Uma das características do jornal é a fragmentação e síntese na transmissão de informações. Não temos a história do processo, porque a matéria é fragmentada, mas tampouco temos uma noção mais próxima do fragmento, porque reduzir complexidade aparece como aspecto central do sentido jornalístico. Em uma matéria curta, a identidade entre o assassinado e os demais moradores é praticamente incompatível com a versão da "justiça popular" que vimos inicialmente. Da mesma maneira, a construção do preso sob o aspecto de algoz é incompatível com a complexidade que os atos de violência assumem na Ilha. Surge, então, uma versão do caso através da descrição do conflito entre presos e moradores, desaparecendo os policiais de cena. Se os fatos veiculados pelo jornal contrastam com a memória popular que se constitui do caso, o contraste da matéria com o trecho do relatório oficial reproduzido acima também não pode ser descartado. Uma nova versão é estabelecida, que não deixa, no entanto, de preservar a memória de alguns aspectos do caso que são verdadeiros: a insatisfação de parte da população com a manutenção do presídio na Ilha. 
Uma última observação precisa ser feita sobre as fronteiras que foram construídas entre os diferentes grupos analisados. Alguns indivíduos compartilhavam as normas de convivência que estavam presentes no interior do sistema prisional (presos, policiais militares e guardas penitenciários), nos vilarejos da região (guardas e moradores) ou ainda na Ilha como um todo (presos, guardas e moradores). No que diz respeito ao uso da violência, por exemplo, a população em geral da Ilha parecia condenar o fato do Ferrugem, um colono ou lavrador que não era policial, ter o direito de usá-la contra os presos. Os policiais, entretanto, pareciam não ter problemas com isso, e os presos demonstraram não legitimar o uso da violência extremada contra eles nem pelo colono, nem pela polícia. A imprensa não percebeu este conflito. Mas se considerarmos uma outra questão, como a desativação do presídio, é possível encontrarmos diferentes grupos, os vinculados ao presídio (guardas e presos) e os moradores. Enfim, como as comunidades de pertencimento não são rígidas, as memórias dos indivíduos que com elas se relacionam são sempre múltiplas e diversificadas.

\section{CONCLUSÃO}

“Tentar esconder o que se passa, sentir-se culpado — estes são os indícios do fim.”

Milan Kundera ${ }^{17}$

Os moradores gostavam de participar da captura dos fugitivos. Eles se sentiam importantes. O Ferrugem não era um caso isolado. Eu quando era criança vi muitos presos serem arrastados ao longo das ruas e a população acompanhando e chutando os presos. As mulheres e as crianças não gostavam, tinham medo, ficavam de longe, mas os homens eram cúmplices (moradora do Abraão).

Acredito que no caso específico da Ilha Grande, diante de uma situação em que práticas oficiais têm procurado o esquecimento, a tentativa de preservar o passado pode se tornar uma questão fundamental. Pequenos cuidados tornam-se cruciais: resguardar os documentos existentes, manter viva a estima em relação a objetos que tendem a ser substituídos por novos, relacionar o passado com a situação presente e com caminhos a serem seguidos no futuro e, antes de tudo, contar e recontar as experiências vivenciadas.

Como dito inicialmente, o objetivo deste trabalho foi investigar os múltiplos aspectos da memória e seu uso para as Ciências Sociais. Não procurei a verdade do caso Ferrugem. Há ainda muitos depoimentos que podem ser pro- 
curados e um trabalho de investigação a ser feito. Mas os depoimentos analisados nos dizem bastante sobre os grupos que rememoram o caso.

Uma grande demarcação que podemos fazer sobre diferentes formas de lembrar é aquela entre as memórias que são voluntárias e obedecem à nossa vontade e às memórias que são involuntárias, ou seja, que surgem sem serem evocadas. Este trabalho lidou basicamente com memórias voluntárias, ou melhor, com memórias que foram resultado da intenção deliberada daqueles que narravam suas lembranças. Embora as memórias analisadas tenham sido narrativas construídas sobre o passado, elas não foram capazes de dar conta do que aconteceu exatamente no passado. Memórias são falhas porque elas têm como referência perspectivas sempre parciais de um acontecimento do passado. As diversas versões do caso Ferrugem mostraram que cada narrador percebeu o assassinato do colono a partir de um ponto de vista e a partir de uma participação parcial no evento. Uma das versões se popularizou e ganhou maior autonomia, mas esta é provavelmente a mais fantasiosa e que menos aspectos comuns tem com as versões narradas por aqueles que estiveram envolvidos diretamente no caso.

Quando diferentes pessoas olham um objeto, elas atribuem diferentes sentidos a este mesmo objeto. Para uns, o que foi importante no caso foi o ajuste de contas entre preso torturado e colono torturador; para outros, entre assassino e policial, para outros ainda, entre uma população civil e a violência de presos e policiais. Neste sentido, é importante inserirmos os relatos em narrativas mais amplas para podermos perceber que mesmo que uma destas narrativas seja incompleta ou equivocada, elas trazem dados significativos sobre os grupos sociais que existem na Ilha, como eles compactuam ou entram em conflito. Pode ser que o relatório oficial omita dados sobre como os presos foram capturados ou traga incorreções sobre o que aconteceu, ainda assim o conteúdo central do documento é partilhado por diversos moradores da Ilha e, como documento, ele é uma fonte que testemunha na sua parcialidade as arbitrariedades que foram cometidas no passado; ele é instrumento ainda atual de litígio social.

Cinco das narrativas analisadas sobre o caso do Ferrugem foram depoimentos pessoais, e estas narrativas, embora pessoais, mostraram-se fortemente vinculadas a determinadas perspectivas defendidas por grupos de pertencimento. O guarda, o policial, o morador, o preso ou o jornalista narraram o caso a partir de perspectivas que podem ser atribuídas a outros membros de seus respectivos grupos. Há também uma diferença a ser apontada no relato da mulher, que evita o confronto e utiliza uma arma sua, o café, como instrumento para combater a violência. Não é possível nos esquecermos o trabalho já citado de Halbwachs, neste momento, quando ele nos mostra que as me- 
mórias, por mais que pareçam expressar experiências estritamente individuais, são constituídas por estruturas sociais mais amplas que antecedem a do indivíduo. Entretanto, como vimos, memórias são múltiplas e combinamse entre si de diferentes formas. A relação entre memória individual e memória coletiva nunca é unilinear e constante.

Nós resgatamos o passado a partir das imperfeições do presente, isto é, a partir das falhas de nossas memórias e a partir dos limites impostos por estruturas coletivas já dadas. Mas o ponto que procurei mostrar ao longo deste trabalho é que estas memórias que são reconstruídas não são arbitrárias, os indivíduos reconstroem o passado a partir de interesses do presente, mas também a partir de percepções mais profundas e constantes que fazem o elo entre passado e presente. É justamente este entrelaçamento entre o passado e o presente que me leva a afirmar que, na reconstrução do passado, embora nós possamos nos esquecer de diversos detalhes sobre o que aconteceu no passado, guardamos dele aquilo que foi importante para nós e que ainda permanece importante para nós. A memória do guarda não foi capaz de reproduzir todos os detalhes do relatório, mas em essência ela reproduziu os aspectos centrais que estavam presentes no relatório e na memória de outros policiais. Nós podemos nos esquecer dos detalhes de um evento passado, reconstruímos os fatos com as peças que estão ao nosso alcance, no entanto, quase sempre, guardamos dele o que foi essencial para nós.

Como em todas as reconstruções e narrativas, a memória construída guarda segredos e fissuras. Tive a oportunidade de apresentar este artigo em um evento promovido pela Universidade do Estado do Rio de Janeiro e pelo Instituto Estadual de Florestas, constituído por palestras e atividades diversas no verão de 2003. Nessa reunião, uma das moradoras pediu a palavra e deu o testemunho que reproduzi acima. Em tom de denúncia, ela afirmou para uma platéia composta de moradores e de turistas, que ela vira muitas vezes em criança os homens do local compactuando com uma violência que hoje está completamente esquecida por todos. A cena dos presos sendo arrastados e humilhados tinha sido contada por muitos, mas pela primeira vez esta cena se configurou com a participação de novos atores: os moradores. Podemos concluir, portanto, que há na memória tanto continuidades quanto invenções, e que no acerto final entre o velho e o novo, o passado nunca está totalmente submisso, pois nós o rememoramos ao longo de um trajeto tortuoso e cheio de conflitos, silêncios e surpresas. 


\section{NOTAS}

${ }^{1}$ Vários trechos do relatório do diretor do Instituto Penal Cândido Mendes (IPCM) ao diretor-geral do Departamento do Sistema Penitenciário (DESIPE), Ofício n. 182/80, de 3 de novembro de 1980, serão utilizados ao longo deste trabalho. O ofício será referido nas demais citações apenas por "Relatório".

${ }^{2}$ Moradores, guardas penitenciários e PMs geralmente referem-se às diversas instituições carcerárias que foram criadas na Ilha como "presídio", muito embora na definição oficial presídio seja a instituição que recebe aqueles que aguardam julgamento, enquanto penitenciária, aqueles que cumprem suas penas. Ao longo deste artigo eu segui o uso corrente da palavra "presídio" para me referir às instituições carcerárias da Ilha Grande.

${ }^{3}$ Ver Bartlett, Frederic Charles. 1961 [1932]. Remembering; a study in experimental and social psychology. The Cambridge psychological library. New York, Cambridge, Eng.,: The Macmillan Company; The University Press, p. 213.

${ }^{4}$ A distinção entre a "história construída" e a "memória viva" é realizada por Pierre Nora (1984), ao estabelecer os marcos de uma nova abordagem capaz de resgatar o passado do Estado Nacional Francês. Ele reuniu uma coletânea de trabalhos que podem ser compreendidos dentro dos marcos da história cultural ou do resgate de memórias coletivas da França.

${ }^{5}$ Ver conceito de quadros sociais da memória em Halbwachs, Maurice. 1925. Les cadres sociaux de la mémoire. Paris: F. Alcan.

${ }^{6}$ Ver noção hermenêutica da História em Gadamer, Hans Georg. 1989. Truth and method. New York: Crossroad.

${ }^{7}$ Próximo a esta abordagem está o trabalho de Ricœur, Paul. 2000. La mémoire, l'histoire, l'oubli. L'ordre philosophique. Paris: Seuil.

${ }^{8}$ Ver Thompson, Paul Richard. 1978. The voice of the past: Oral history. Oxford [Eng.]; New York: Oxford University Press, ou ainda Amado, Janaina e Marieta de Moraes Ferreira (eds.), 1996. Usos e abusos da história oral. Rio de Janeiro: Fundação Getúlio Vargas.

${ }^{9}$ As referências citadas são Bosi, Ecléa. 1987. Memória e sociedade: Lembranças de velhos. São Paulo: T.A.Queiroz: Editora da Universidade de São Paulo e Nora, Pierre. 1984. Les lieux de mémoire. Bibliothèque illustrée des histoires. Paris: Gallimard.

${ }^{10}$ São muitos os exemplos, podemos destacar os trabalhos de Middleton, David and Derek Edwards. 1990. Collective remembering. Inquiries in social construction. London; Newbury Park, Calif.: Sage Publications; Anderson, Benedict R. 1991. Imagined communities: Reflections on the origin and spread of nationalism. London; New York: Verso e Smith, Anthony D. 1999. Myths and memories of the nation. New York: Oxford University Press.

${ }^{11}$ Bergson, Henri. 1985. Matière et mémoire: Essai sur la relation du corps à l'esprit. Paris: Presses universitaires de France. Pp. 83-96.

${ }^{12}$ Além de Walter Benjamin, podemos citar os trabalhos dos psicólogos Frederic Bartlett e 
Ulric Neisser (Benjamin, Walter. 1968. On some motifs in baudelaire. In Illuminations, ed. Hannah Arendt. New York: Harcourt Brace \& World, pp. 155-200; Bartlett, Frederic. op. cit.; e Neisser, Ulric. 1982. Memory observed: Remembering in natural contexts. San Francisco: W.H. Freeman.)

${ }^{13}$ Este argumento aparece desenvolvido em dois trábalos de Myrian S. Santos: Santos, Myrian Sepúlveda. 1998. A luta da memória contra o esquecimento. Síntese Nova Fase 25, n. 82, pp. 351-368, e Santos, Myrian Sepúlveda. 2001. Historicismo e verdade em políticas da memória. In Modernidade crítica e modernidade acrítica (ed). Héctor Ricardo Leis, Ilse Scherer-Warren and Sergio Costa. Florianópolis: Cidade Futura, pp. 47-63.

${ }^{14}$ Conforme Bartlett, Frederic. Op. cit.

${ }^{15}$ Conforme Halbwachs, Maurice. Op. Cit.

${ }^{16}$ Moradores, guardas e PMs chamam de "furniço" um saco de mantimentos que os guardas davam para moradores em troca do serviço. Provavelmente corruptela da palavra fornimento.

${ }^{17}$ Kundera, Milan. 1980. The book of laughter and forgetting. New York: A. A. Knopf. 